\title{
ПРОИЗВЕДЕНИЯ ВИКТОРА ПЕЛЕВИНА В КОНТЕКСТЕ ПОСТСТРУКТУРАЛИЗМА
}

\section{Works of Victor Pelevin in the Context of Poststructuralism}

Keywords: Viktor Pelevin, poststructuralism, consumerism, liquid modernity, capitalism

Contact: Uniwersytet Śląskiw Katowicach; pmlaniewski@gmail.com

Конец XX века для многих обществ был переломным моментом. Старая модель жизни, основана на тяжелой промышленности и связанной с ней надежности и безопасности, начала исчезать. Ее место занял другой образец - жизнь стала более неопределенной, в экономике промышленность потеряла значение и передала первенство услугам не требующим ни крупных зданий, ни трудоустройства. Обычный человек, уже привыкший к условиям обеспечивающим спокойную и стабилизированную жизнь, был вынужден подчиниться им полностью. Многие социологи и философы, в том числе Ж. Бодрийяр, утверждают, что он даже потерял свое человечество и превратился в объект потребления ${ }^{1}$. Именно потребление, нестесненное никакими границами, стало стимулятором нового типа общества, с которым человек впервые столкнулся в Америке пятидесятых годов XX столетия. Согласно той доминанте, новообразованное общество получило и название - оно стало обществом потребления.

Общество потребления, вытекающее из той же философской основы общество текучей современности, и сопровождающие их изменения, быстро стали объектом анализа как ученых, так и многих писателей. Особый интерес к этим явлениям проявляли, и постоянно проявляют, писатели связаны с постмодернизмом - т. е. понятием, неизбежной частью которого становится потребление. Не исключено, что именно этот фактор повлиял на основные черты культуры постмодерна. Согласно Ф. Джеймсону, постмодернизм отличает: «стирание границ между высокой и массовой, или коммерческой, культурой»,

\footnotetext{
${ }^{1}$ Бодрийяр, Ж. Общество потребления. Москва: Республика, 2006, с. 5.
} 
«новое отсутствие глубины», «кризис историчности», «исчезновение тематики времени и временности», «угасание аффектов», а также «смерть субъекта» ${ }^{2}$.

Самым известным русским писателем, который очень много внимания уделяет как теме потребления, так и его влияния на поведение русского общества, безусловно является Виктор Олегович Пелевин. Автор Generation «П» родился в 1962 году в Москве. После окончания Московского энергетического института он поступил в легендарный Литературный институт им. Горького, но после двух лет учебы был отчислен из вуза с примечанием «как утративший связь». Начало его литературной деятельности совпало с горбачевской перестройкой; дебютное произведение Пелевина Колдун Игнат и люди было опубликовано в 1989 году. За первое десятилетие писатель успел издать четыре романа, в том числе самый популярный, экранизованный В. Гинзбургом в 2011 году Generation П. Сочинение пользуется неслыханным успехом, его тираж составил 360 тысяч экземпляров, а читателям, влюбившимся в Пелевина после прочитания его предыдущего романа Чапаев и пустота (1996), не хотелось ждать до его официальной премьеры, в результате чего книга была выкрадена и закинута для скачания в Интернет ${ }^{3}$.

Однако после первоначального увлечения романом, быстро появились и отрицательные коментарии. Критиков удивлял язык произведения, который Пелевин вводил в русскую литературу - вместо качественного языка, характерного для высокой прозы, писатель использовал язык «нового журнализма», соединяющий некое изящество с небанальной, современной формой. Это новшество имело своих приверженцев, заявляющих, что Пелевин «развернул отечественную словестность к XXI веку», но встречалось и с более отчетливыми осуждениями. Итак, Л. Рубинштейн пришел к выводу, что «от распада языка пострадала и вся конструкция романа - его структура не выдерживает замысла» ${ }^{4}$. Самой важной оказалась неподдельность стиля Пелевина, на которую обратил внимание С. Москалев: «Всякая пелевинская книга отражает его тогдашний круг общения (...) ко времени написания Generation "П" стал (Пелевин - Р. Ł.) тусоваться с рекламно-бомодными, стал ходить по приемам, к послам, атташе» 5 .

Не исключено, что именно благодаря этим превосходным знаниям мира рекламы и маркетинга Пелевин сумел создать антиутопический мир. В нем

\footnotetext{
${ }^{2}$ Скоропанова, И. С. Русская постмодернистская литература: новая философия, новый язык. СанктПетербург: Невский простор, 2000, с. 34.

${ }^{3}$ Полотовский, С., Козак, Р. Пелевин и поколение пустоты. Москва: Манн, Иванов и Фербер, 2012, с. 54.

${ }^{4}$ Там же, с. 55.

${ }^{5}$ Там же. 
пришло жить не только Вавилену Татарскому, главному герою романа, выпускнику литинститута, который во время постройки русского капитализма стал заниматься манипуляторской рекламой, но и всем его сверстникам и преемникам, людям поколения П, поколения Пепси, где реклама превосходит реальность. Описанная Пелевиным система является комплектной, она затрагивает все сферы жизни, а созданная в романе модель русского общества 1990-х годов несомненно стала образцом для других писателей и исследоватедей.

Новое тысячелетие не принесло изменений - лишь увеличился масштаб происходящих в мире процессов. Согласно 3. Бауману в настоющее время границы теряют свою роль, а кризисы, происходяще в любой точке земного шара, мгновенно отражаются на остальных регионах 6 . Русское общество преобразовалось и приспособилось к новым условиям; возникла обладающая огромным богатством каста олигархов, повысился средний уровень жизни горожан, распространились новые технологии, которые стали неизбежными элементами существования современного человека. Следует отметить, что мир и его постоянное движение никогда не перестали быть объектом внушения Пелевина. Писатель с увлечением следит за абсурдами, которыми усеян современный мир и пытается бороться с ними с помощью единственного оружья, которым обладает артист - гротеска и сатиры.

В 2010 году появилось очередное произведение Пелевина - обращающееся к проблематике затронутой раньше в Generation «П»- сборник, содержащий две повести и три рассказа, под заглавием Ананасная вода для прекрасной дамы. Для многих читателей эта книга стала своеобразным возвращением Пелевина к прежней позиций - утверждает С. Полотовский ${ }^{7}$. Мотивом, соединяющим все находящиеся в сборнике произведения, является, кроме повсеместной иронии, четкая насмешка над состоянием современного общества и его продуктов. Пелевин в открывающих книгу повестях подвергает критике современную политическую систему. Главный герой Onepauиu «Burning Bush» Семен Левитан (преподователь английского, обладающий голосом легендарного радио-диктора Юрия Левитана) вовлечен в секретную операцию, в которой изображает голос Бога в разгаворах с президентом США - Джорджом Бушом младшим. Великолепно имитирующий голос бога, знающий теологию и вдобавок стимулированный наркотиками англист еврейского происхождения, с легкостью входит также в роль дьявола. На этот раз его талант используется против русской

\footnotetext{
${ }^{6}$ Подвойский, Д. Куда течет «текучая современность»? Режим доступа: http://polit.ru/article/2011/06/02/ podvoysky_bauman/ (2020-04-25).

${ }^{7}$ Полотовский, С., Козак, Р. Пелевин и поколение пустоты. Москва: Манн, Иванов и Фербер, 2012, с. 123.
} 
власти. Зенитные кодексы Аль-Эфесби касаются войны в Афганистане и связанной с ней утечкой информации в WikiLeaks. Вновь оказывается, что миром управляют не столько политики, сколько пиар - американцы создают дроны, которые не только уничтожают врагов, но сразу генерируют телевизионный ток-шоу. В нем реально несуществующий экипаж дрона, используя огромное количество цитатов из популярных сериалов, повтаряет тривиальности про войну и защиту прав человека. Эту, казалось бы, гениальную систему уничтожает агент ФСБ Савелий Скотенков (его кличка Аль-Эфесби), который разоблачает лицемерие американцев.

Новообразованное постмодернистское общество быстро разрушило все устои системы присутствующей в России, фактически, еще со времен царей. Как предполагает 3. Бауман, в первую очередь новые люди, т. е. ничем неограниченные потребители, уничтожили все связи соединяющие единицы. Как родство, так и дружба потеряли свои значения, стали незначительным реликтом ушедшего времени21. Вследствие того, были созданы другие ценности, благодаря которым люди смогли осознаваться и создавать новую иерархию. Основным фактором отилчающим и определяющим граждан, является их способность приспособиться к новым условиям. Исходя из этой предпосылки, американский социолог Т. Беблен выделяет две группы людей - первая из них не в состаянии найти свое место в новом обществе, вторая, т. наз. праздный класс, быстро начинает преобразовывать свое окружение и, фактически, становится господствуюшим классом ${ }^{8}$.

Праздный класс отличает демонстративное потребление, с помощью которого он определяется полностью. Его члены ежедневно принимают участие в непрекращающейся борьбе за статус и одобрение членами собственной группы. В силу того, видоизменению подверг весь каталог ценностей - потребление стало мифом, товары потеряли свою фактическую стоимость, становясь символами самого потребления. Согласно И. Солдатенко: «Владение большей собственностью предполагает повышение престижа статуса, рост социального положения. Поэтому необходимо постоянно демонстрировать свое богатство в целях формирования и поддержания общественного мнения» 9.

Бурный процесс преобразования русского общества находит отражение уже в первых строках романа В. Пелевина Generation «П». Заголовочное поколение «П» является не только первым российским поколением, которое стало

\footnotetext{
${ }^{8}$ Бауман, 3. Текучая современность. Санкт Петербург: Питер, 2008, с. 9.

${ }^{9}$ Солдатенко, И. Процесс потребления в современной Россий - мифы и реалии. Режим доступа: http: cyberleninka.ru/article/n/protsess-potrebleniya-v-sovremennoy-rossii-mify-i-realii (2020-04-28). 
жить согласно принципу вещизма, оно стало первым поколением, которое требовало потребления, и, в конце концов, само выбрало загадочное П - т. е. Пепси, напиток, который автор отождествляет с западным, сосредоточенным на консумеризме, стилем жизни: «Когда-то в России и правда жило беспечальное юное поколение, которое улыбнулось лету, морю и солнцу - и выбрало Пепси. Сейчас уже трудно установить, почему это произошло. Наверно, дело было не только в замечательных вкусовых качествах этого напитка. И не в кофеине, который заставляет ребятишек постоянно требовать новой дозы, с детства надежно вводя их в кокаиновый фарватер. И даже не в банальной взятке - хочется верить, что партийный бюрократ, от которого зависело заключение контракта, просто взял и полюбил эту темную пузырящуюся жидкость всеми порами своей разуверившейся в коммунизме души» ${ }^{10}$.

В самом начале романа Пелевин указывает причины этого выбора - набор ценностей, прививаемых людям при коммунизме, потерял свою актуальность, перестал соответствовать новому времени. Общество, только что открывшееся на запад, осознало, что существует жизнь на много легче и привлекательнее. Исчезло убеждение, что Советский Союз и его наследник - Россия - являются самой могучей страной в мире; появились сомнения и жажда познания того запрещенного мира, с которым русский человек сталкивался благодаря телевидению и новым средствам связи.

Согласно рассказчику, первое столкновение гражданина Российской Федерации с могучим механизмом потребления царствующим на Западе, имело лицо обезьян, которые сыграли главные роли в вышеупомянутом рекламном клипе. Бренд Пепси, будучи одним из упор мирового консумеризма, был принят российским обществом энтузястически, для типичного россиянина он являлся безобидным симптомом наступающих перемен, а не воплощением потребительского зла, с которым ассоциировали его некоторые постмодернистские мыслители.

Можно прийти к выводу, что общество, которое с таким увлечением разрешает манипулировать собой американским специалистам по рекламе, придумавшим клип Пепси, становится беззащитным и подвергается постоянной угрозе попадать во все новые виды зависимости. На ту же опасность обращает внимание рассказчик романа Пелевина: «Немного обидно было узнать, как именно ребята из рекламных агентств на Мэдисон-авеню представляют себе свою аудиторию, так называемую target group. Но трудно было не поразиться их

\footnotetext{
${ }^{10}$ Пелевин, В. Generation «П». Москва: Вагриус, 2002, с. 11.
} 
глубокому знанию жизни. Именно этот клип дал понять большому количеству прозябавших в России обезьян, что настала пора пересаживаться в джипы и входить к дочерям человеческим» ${ }^{11}$.

Следует отметить, что само понятие манипуляции эволюционировало. Первоначально оно касалось едва объектов, мертвых вещей, податливых на воздействие со стороны человека. Современный подход к этой теме не только расширил потенциальную цель манипуляции также на людей, но, фактически, сосредоточился на ней ${ }^{12}$. С. Кара-Мурза определяет манипуляцию таким образом: «это программирование мнений и устремлений масс, их настроений и даже психического состояния с целью обеспечить такое их поведение, которое нужно тем, кто владеет средствами манипуляции» ${ }^{13}$.

Трудно не заметить, что в новой системе человек воспринимается едва в качестве потребителя. Эта функция не требует ни знаний, ни характера, ни других ценностей, которые определяли человека до возникновения общества потребления. Исходя из таких предпосылок, сравнение человека с обезьяной является не только удачным, но и чрезмерно благосклонным, так как с обезьяны требуется больше, чем с неспособного принимать самостоятельные решения автомата. Однако - утверждает 3. Бауман - нельзя оценивать таким образом целое общество, так как оно, как целое, погибло вместе с ушедшим, тяжелым образом жизни ${ }^{14}$.

Пелевин сосредоточивает свое внимание на двух типах людей представителях праздного класса, т. е. тех, кто приспособился к новым условиям, и лицах, которые полностью их отвергли, приговаривая себя к фактическому изгнанию. Остальные - т. е. члены класса потребителей, являются лишь громадной толпой, лишенной права на самоопределение.

Стоит подчеркнуть, что даже «праздный класс» не является однородным. К нему принадлежат не только люди, зарабатывающие на обычных потребителях, но и «хищники» высшего порядка, которые используют наивность обоих, подчиненных им, групп людей. Герой романа Пелевина, Вавилен Татарский, работая копирайтером, пишущим сценарии к рекламным роликам, даже не пытается удовлетворить ожидания своих клиентов (т. е. бизнесменов и крупных производителей различных товаров), а хочет их просто обмануть. Как их, так

\footnotetext{
${ }^{11}$ Пелевин, В. Generation «П». Москва: Вагриус, 2002, с. 22.

${ }^{12}$ Федотова, М. Проблема манипуляции сознанием в романе В. Пелевина "Generation "П"». Режим доступа: fullref.ru/job_da9b9364c99c0ccdeb3592679be7c4c6.html (2020-04-28).

${ }_{13}$ Кара-Мурза, С. Манипуляция сознанием. Режим доступа: rumol.ru/files/library/books/kara-murza/karamurza-manipul.pdf (2020-04-28).

${ }^{14}$ Бауман, 3. Текучая современность. Санкт Петербург: Питер, 2008, с. 35. 
и потенциальных получаетелей реклам, он воспринимает как объекты манипуляции.

Весь формирующийся рекламный рынок фактически является полной бодрийровской симулякрой. Собственная цель рекламы, т. е. соответствующее рекламирование продукта с целью увеличения его продажы, отодвигается на задний план, уступая место продажи рекламы как полноправного товара. Эта сложная система существует только благодаря бессознательности двух групп людей, зависимых от реклам - их заказчиков и получателей, т. е. потребителей, которым они предназначены. Только создатели, сохраняя некое превосходство над другими людьми, проводят рыночную игру сознательно и могут одержать победу.

Целью Вавилона Татарского и его коллег является зарабатывание денег. Именно эти деньги являются единственной ценностью, определяющей не только их работу, но и жизнь. Этот подход характерный для нового поколения - он лишен всей романтической нагрузки, которая сильно влияла на поколения допотребительской эры.

Современность не обращает внимания на такие пустые мысли, как самоосуществление или работу на благо общества, вместо того предлагает очень простой ориентир - количество заработанных денег.

Если рассматривать вопрос роли рекламы в современном обществе шире, можно прийти к выводу, что она является очередной формой управления и влияния на общество. Как подчеркивает И. Скоропанова, такой подход к этой теме представляет и Ж. Бодрийяр, французский ученый утверждает, что именно реклама пришла на смену лишенным актуальности механизмам принудительного социального строя, действуя при этом как источник непрекращающегося обмана - втолковывающего гражданам, что они нуждаются в том, что фактически является лишним.

Рекламный ролик стал опредителем, с помощью которого потребители в состоянии разбираться в том, что является модным и престижным, а что уже утратило свою актуальность. Этот существующий в телевизионном измерении клип, по мнению Пелевина, сам создал своего получателя, так как подвергающий манипуляции зритель, по сути дела, не обладает возможностью принимать сознательное решение. В романе его определяют званием Homo Zapiens (от англ. Zapping, т. е. быстрое переключение с одной программы на другую). Ното Zapiens связан с телевидением невидимой нитью, определяющей его полностью. Реклама является для него показателем его собственного счастья и достигнутых 
целей, телевидение само по себе становится не только неотьемлемым элементом жизни, но и стимулятором, будучим массовым наркотиком.

Потребление и все связанные с ним явления становятся важнейшей частью жизни современного человека. Они несут ответственность за практически все элементы окружающей нас действительности, проникают в интимную сферу жизни и манипулируют нашим подсознанием и менталитетом. Основой общественной жизни становится механизм приобретения, который приходит на смену чувствам и общению, вытесняет все реликты ушедшей модели жизни.

Социально-экономическая трансформаця, которая предоставила возможность возникновения и развития русского потребительского общества, произошла лишь в начале 1990-ых годов. Она привела к ряду крупных изменений, как в общественной, так и в личной сферах жизни человека. Почти единообразное советское общество сразу распалось, быстро преобразовалось и приспособилось к новым условиям. Этот поворотный пункт в истории России стал объектом углубленного анализа как экономистов, так философов и художников.

\section{Summary}

Many of Victor Pelevin's works focus on the issue of consumerism. Social and economic transformation led to a number of major changes in both the public and personal spheres of human life. Almost uniform Soviet society immediately disintegrated, quickly transformed and adapted to the new conditions. This turning point in Russian history has been the subject of in-depth analysis by economists, philosophers and artists alike. The writer, using deconstruction and poststructural techniques, announces these phenomena and observes the development of consumerism in Russia and in the world.

\section{Литература}

Бауман, 3. Текучая современность. Санкт Петербург: Питер, 2008.

Бодрийяр, Ж. Общество потребления. Москва: Республика, 2006.

Кара-Мурза, С. Манипулящия сознанием. Режим доступа: rumol.ru/files/library/ books/kara-murza/kara-murza-manipul.pdf (2020-04-28).

Пелевин, В. Generation «П». Москва: Вагриус, 2002.

Подвойский, Д. Куда течет «текучая современность»? Режим доступа: http://polit.ru/article/2011/06/02/podvoysky_bauman/(2020-04-25). 
Полотовский, С., Козак, Р. Пелевин и поколение пустотьл. Москва: Манн, Иванов и Фербер, 2012.

Скоропанова, И. С. Русская постмодернистская литература: новая философия, новый язык. Санкт-Петербург: Невский простор, 2000.

Солдатенко, И. Процесс потребления в современной Россий - мифы и реалии. Режим доступа: http: cyberleninka.ru/article/n/protsess-potrebleniya-vsovremennoy-rossii-mify-i-realii (2020-04-28).

Федотова, М. Проблема манипуляции сознанием в романе В. Пелевина «Generation “П”». Режим доступа: fullref.ru/job_da9b9364c99c0ccdeb35926 79be7c4c6.html (2020-04-28). 